Actuators: B. Chemical

Elsevier Editorial System(tm) for Sensors \&

Manuscript Draft

Manuscript Number: SNB-D-16-04981R1

Title: A screen-printed voltammetric electronic tongue for the analysis of complex mixtures of metal ions

Article Type: Research Paper

Keywords: voltammetric electronic tongue; screen-printed electrodes; modified electrodes; metal determination; stripping voltammetry; partial least square regression

Corresponding Author: Dr. Núria Serrano,

Corresponding Author's Institution:

First Author: Clara Pérez-Ràfols

Order of Authors: Clara Pérez-Ràfols; Núria Serrano; José Manuel DíazCruz; Cristina Ariño; Miquel Esteban

Abstract: A voltammetric electronic tongue was constituted by four screen-printed modified electrodes: a carbon nanofiber modified electrode, an ex-situ antimony film electrode prepared from carbon nanofiber modified electrode, and two carbon nanofiber electrodes chemically modified with Cys and GSH. The tongue was successfully applied to the analysis of a complex mixture of metal ions (4 analytes and 2 interferences) by differential pulse anodic stripping voltammetry. Each sensor was firstly studied for the determination of each metal separately confirming that all electrodes showed differentiated response for the metals. The obtained voltammetric signals provided by the sensor array were processed by Partial Least Squares regression (PLS) to resolve the overlapped nature of the obtained multimetal stripping measurements. This PLS model was built considering a hierarchical model in order to reduce the large amount of data. The method was applied to synthetic mixtures of $\mathrm{Cd}(\mathrm{II}), \mathrm{Pb}(\mathrm{II}), \mathrm{Tl}(\mathrm{I})$, and $\mathrm{Bi}(\mathrm{III})$ in the presence of $\mathrm{Zn}(\mathrm{II})$ and In(III) at the levels of $\mu \mathrm{g}$ L-1 and successfully validated with correlation coefficients of both calibration and prediction higher than 0.9 obtained from predicted vs. expected concentration graphs. Moreover, the simultaneous determination of $\mathrm{Cd}(\mathrm{II}), \mathrm{Pb}(\mathrm{II}), \mathrm{Tl}(\mathrm{I})$, and Bi(III) in the presence of $\mathrm{Zn}$ (II) and In(III) in a spiked tap water was also satisfactory achieved, providing comparable results to those obtained by ICP-MS . 


\section{A screen-printed voltammetric electronic tongue for the analysis of complex mixtures of metal ions}

Clara Pérez-Ràfols, Núria Serrano*, José Manuel Díaz-Cruz, Cristina Ariño, Miquel Esteban

Departament d’Enginyeria Química i Química Analítica, Facultat de Química, Universitat de Barcelona, Martí i Franquès 1-11, E-08028 Barcelona (Spain)

Phone: 0034934039274, fax: 0034934021233, e-mail: nuria.serrano@ub.edu

* to whom correspondence should be addressed

\section{ABSTRACT}

A voltammetric electronic tongue was constituted by four screen-printed modified electrodes: a carbon nanofiber modified electrode, an ex-situ antimony film electrode prepared from carbon nanofiber modified electrode, and two carbon nanofiber electrodes chemically modified with Cys and GSH. The tongue was successfully applied to the analysis of a complex mixture of metal ions (4 analytes and 2 interferences) by differential pulse anodic stripping voltammetry. Each sensor was firstly studied for the determination of each metal separately confirming that all electrodes showed differentiated response for the metals. The obtained voltammetric signals provided by the sensor array were processed by Partial Least Squares regression (PLS) to resolve the overlapped nature of the obtained multimetal stripping measurements. This PLS model was built considering a hierarchical model in order to reduce the large amount of data. The method was applied to synthetic mixtures of $\mathrm{Cd}(\mathrm{II}), \mathrm{Pb}(\mathrm{II}), \mathrm{Tl}(\mathrm{I})$, and $\mathrm{Bi}(\mathrm{III})$ in the presence of $\mathrm{Zn}(\mathrm{II})$ and $\mathrm{In}(\mathrm{III})$ at the levels of $\mu \mathrm{g}$ 
$\mathrm{L}^{-1}$ and successfully validated with correlation coefficients of both calibration and prediction higher than 0.9 obtained from predicted vs. expected concentration graphs. Moreover, the simultaneous determination of $\mathrm{Cd}(\mathrm{II}), \mathrm{Pb}(\mathrm{II}), \mathrm{Tl}(\mathrm{I})$, and $\mathrm{Bi}(\mathrm{III})$ in the presence of $\mathrm{Zn}(\mathrm{II})$ and $\mathrm{In}(\mathrm{III})$ in a spiked tap water was also satisfactory achieved, providing comparable results to those obtained by ICP-MS.

Keywords: voltammetric electronic tongue, screen-printed electrodes, modified electrodes, metal determination, stripping voltammetry, partial least square regression

\section{INTRODUCTION}

Heavy metals are natural components of the earth crust and can be released to the environment from both natural and anthropogenic sources such as forest fires, volcanic eruptions, sea spray, biogenic aerosols, mineral extraction, metal processing and incineration of pharmaceutical products, batteries, plastics and electrical goods among others $[1,2]$. In contrast to other toxic substances, heavy metals are no biodegradable. This fact increases the risk to human health that represent human or anthropogenic contributions to air, water, soil and food by modifying their speciation [3]. This risk is even higher due to heavy metals tend to bioaccumulate and biomagnificate $[4,5]$. Some heavy metals are essential for the human life in small concentrations. However, most of these metals are harmful when they are found at higher concentrations, being lead, cadmium, arsenic and mercury the most toxic. Heavy metals can be incorporated to the human body through the air, water, food or skin adsorption [4]. Therefore, monitoring heavy metals is very important both for human health and environment. In the last years different techniques were applied for the determination of heavy metals, being atomic 
absorption spectroscopy, inductively coupled plasma mass spectrometry or inductively coupled plasma atomic emission spectroscopy the most representative ones [6-8]. Nevertheless, these techniques require long times of analysis, expensive instruments and trained personal. A faster and cheaper alternative that requires simple and portable instrumentation is given by electroanalytical techniques, which present excellent detection limits, sensitivity to the presence of different metals species and ability to multielement determination [9].

In voltammetric measurements of metal ions the electrode usually works as a singleelectrode sensor which allows the simultaneous determination of several metal ions when non-overlapped peaks are obtained, i.e. the determination of $\mathrm{Zn}(\mathrm{II}), \mathrm{Cd}(\mathrm{II}), \mathrm{Pb}$ (II) and $\mathrm{Cu}(\mathrm{II})$ with the classical hanging mercury drop electrode $[10,11]$. However, when the solution contains a complex mixture of metal ions with intricate voltammetric responses (overlapped peaks, different interactions between metals...) the use of a single- electrode sensor does not allow its resolution. To solve these more complex systems a good strategy can be the use of several electrodes grouped in arrays of sensors with low selectivity that present a cross-response performance, giving rise to a multisensor array or (bio)electronic tongue, in which each electrode is different searching for a multivariate response [12-15]. Although the use of voltammetric tongues for electroanalytical purposes requires a larger amount of samples for calibration and the use of a multichannel potentiostat, these disadvantatges can be overcome if the achieved information is better than that provided by a single sensor.

An essential aspect of any electronic tongue is data analysis. In particular, voltammetric tongues generate large amounts of data, which makes necessary a first step in order to preprocess and compress them prior to building the chemometric model. This preprocessment usually focuses on making data independent from units, removing 
redundant information or enhancing signal-to-noise ratio. In order to build the model different multivariate chemometric tools such as principal component analysis (PCA), partial least squares regression (PLS) or artificial neural network (ANN) have been used to maximize the information achieved from the voltammetric data set using the sensor array, that a priori are difficult to analyse $[12,16,17]$.

The use of arrays of voltammetric sensors has recently enabled an application very much desirable from the industrial sector, which is the use of electronic tongue systems to monitor and to detect defects during production of beverages and food [12]. In addition, sensor arrays are also useful in other research fields such as environmental analysis or bioanalysis [14,18-21]. In particular, voltammetric electronic tongues have been recently applied for metal ion determination in simple metal mixtures [22-25]. Nevertheless, to the best of our knowledge no more than 3 different metals were considered.

To ensure the desired cross-response of the electrode array the combination of different sensors modified following different strategies can be useful. In this sense, electrodeposition of metal films onto electrode surfaces [26,27] or chemical modification by electrografting with aryl diazonium salts [28] are two modification processes well known that can lead to sensors presenting a very different voltammetric response.

Nowadays, the screen-printing technology is well established for the production of sensors for electrochemical purposes. This technology allows the mass production of quite reproducible single-use devices with accessible and low cost character that usually incorporate a three-electrode configuration (working, reference and counter) on the same strip. Moreover, recent advances in this technology also allow the production of devices with different designs and the use of different inks (carbon, gold, silver, 
platinum...) that can include nanomaterials too [26,29-33]. In fact, the use of carbonbased nanomaterials, and in particular carbon nanofiber (CNF), as substrates for electrode modifications has been reported to provide sensors with a better analytical performance due to their enhanced real surface area [34,35].

Thus, the coupling of SPEs with a voltammetric electronic tongue presents an attractive option for the determination of complex mixtures of heavy metal ions.

In this respect, this study presents a voltammetric electronic tongue which employs an array of sensors constituted by a carbon nanofiber modified screen-printed electrode (SPCE-CNF), an ex-situ antimony film electrode prepared from carbon nanofiber modified screen-printed electrode (SbSPCE-CNF), and two chemically modified sensors in which Cys and GSH were immobilized on aryl diazonium salt monolayers anchored to the surface of a carbon nanofiber modified screen-printed electrode (CysSPCE-CNF and GSH-SPCE-CNF, respectively) to consider for the first time the multivariate analysis of a really complex metal ion mixture including $\mathrm{Cd}(\mathrm{II}), \mathrm{Pb}$ (II), $\mathrm{Tl}(\mathrm{I}), \mathrm{In}(\mathrm{III}), \mathrm{Zn}(\mathrm{II})$, and $\mathrm{Bi}(\mathrm{III})$ in natural water samples. The electrochemical responses obtained from anodic stripping voltammetry (ASV) were used as departure information and the data treatment was performed with appropriate PLS model.

\section{EXPERIMENTAL SECTION}

\subsection{Chemicals and Solutions.}

All chemicals were of analytical grade and used without additional purification. $\mathrm{Sb}$ (III) $1.000 \mathrm{mg} \mathrm{L}^{-1}$ atomic absorption standard solution was provided from Merck (Darmstadt, Germany). Potassium ferrocyanide $\mathrm{K}_{4}\left[\mathrm{Fe}(\mathrm{CN})_{6}\right] \cdot 3 \mathrm{H}_{2} \mathrm{O}, \quad$ 2-(N-morpholino)ethanesulfonic acid (MES), nitric acid, hydrochloric acid, sodium acetate, acetic acid 
and glutathione (GSH), in the reduced form, with purity greater than $99 \%$ were purchased from Merck. $\quad \mathrm{N}$-hydroxysulfosuccinimide $\quad$ (sulfo-NHS), $\quad \mathrm{N}$-(3dimethylaminopropyl)- $N$ '-ethylcarbodiimide hydrochloride (EDC), 4-aminobenzoic acid (ABA), sodium nitrite, methanol, perchloric acid, sodium monophosphate, potassium dihydrogen phosphate, and L-cysteine (Cys) with purity greater than $99 \%$ were provided by Sigma-Aldrich (St. Louis, MO, USA). Potassium ferricyanide $\mathrm{K}_{3}\left[\mathrm{Fe}(\mathrm{CN})_{6}\right]$ was supplied by Panreac (Barcelona, Spain). $\mathrm{Zn}(\mathrm{II}), \mathrm{Cd}(\mathrm{II}), \mathrm{Pb}(\mathrm{II}), \mathrm{Tl}(\mathrm{I})$, In(III) and $\mathrm{Bi}(\mathrm{III})$ stock solutions $10^{-2} \mathrm{~mol} \mathrm{~L}^{-1}$ were prepared from $\mathrm{Pb}\left(\mathrm{NO}_{3}\right)_{2} \cdot 4 \mathrm{H}_{2} \mathrm{O}$, $\mathrm{Cd}\left(\mathrm{NO}_{3}\right)_{2} .4 \mathrm{H}_{2} \mathrm{O}, \mathrm{Zn}\left(\mathrm{NO}_{3}\right)_{2} .4 \mathrm{H}_{2} \mathrm{O}, \mathrm{TlCl}, \mathrm{In}_{2}\left(\mathrm{SO}_{4}\right)_{3} .5 \mathrm{H}_{2} \mathrm{O}$ and $\mathrm{Bi}(\mathrm{III}) 1000 \mathrm{mg} \mathrm{L}^{-1}$ atomic absorption standard solution respectively supplied by Sigma-Aldrich. Ultrapure water (Milli-Q plus 185 system, Millipore) was used in all experiments.

Tap water sample was collected in the laboratory from the local water distribution network, managed by Agbar Company (Barcelona; http://www.agbar.es/eng/home.asp) and mostly using water coming from Llobregat River.

\subsection{Instrumentation.}

An Autolab System PGSTAT12 (EcoChemie, The Netherlands), in a multichannel configuration, using GPES Multichannel 4.7 software package (EcoChemie) was used to perform differential pulse anodic stripping voltammetric (DPASV) measurements. The voltammetric cell was constituted by an $\mathrm{Ag}|\mathrm{AgCl}| \mathrm{KCl}\left(3 \mathrm{~mol} \mathrm{~L}^{-1}\right)$ reference electrode (to which all potentials are referred) provided by Metrohm (Switzerland), the four working screen-printed electrodes (SPEs) modified with CNF, Sb film, Cys and GSH respectively, and a carbon counter electrode from one of the SPEs as a common counter electrode. The working SPEs were prepared from commercial carbon nanofiber modified screen-printed disk electrodes (ref. 110CNT, DS SPCE) of $4 \mathrm{~mm}$ diameter 
supplied by Dropsens (Oviedo, Spain). Four flexible cables ref. (CAC, DropSens) were used to connect the SPEs to the Autolab System (Figure 1).

For pH measurements, a Crison micro pH 2000 pH-meter was used.

All measurements were carried out without oxygen removal and at room temperature $\left(20^{\circ} \mathrm{C}\right)$.

Inductively coupled plasma mass spectrometry Perkin-Elmer model Elan 6000 (USA) was used for ICP-MS measurements.

\subsection{Preparation of modified SPEs.}

\subsubsection{Carbon nanofiber modified screen-printed electrode (SPCE-CNF): SPCE-CNF}

can be used as it is commercially acquired without any previous treatment before measurements.

2.3.2. Ex-situ antimony film electrode (ex-situ-SbSPCE-CNF): The SPCE-CNF, the auxiliary and the reference electrodes were immersed into a plating solution containing $0.01 \mathrm{~mol} \mathrm{~L}^{-1} \mathrm{HCl}$ and $50 \mathrm{mg} \mathrm{L}^{-1}$ of $\mathrm{Sb}(\mathrm{III})$. An $\mathrm{E}_{\mathrm{d}}=-0.50 \mathrm{~V}$ was applied during $300 \mathrm{~s}$ with solution stirring, followed by a rest period (without stirring) of $20 \mathrm{~s}$. This methodology was previously tested showing a very high repetitivity and reproducibility [36].

\subsubsection{Glutathione modified electrode (GSH-SPCE-CNF): GSH was immobilized on} aryl diazonium salt monolayers anchored to the surface of SPCE-CNF [35]. Briefly, firstly the aryl diazonium salt is generated by adding $2 \mathrm{mmol} \mathrm{L}^{-1}$ of $\mathrm{NaNO}_{2}$ to a cooled solution of $73 \mathrm{mmol} \mathrm{L}^{-1}$ of $\mathrm{ABA}$ in $1 \mathrm{~mol} \mathrm{~L}^{-1} \mathrm{HCl}$. After mixing for $30 \mathrm{~min}$ in an ice bath, the electrochemical grafting process was conducted by the application of 15 cycles of cyclic voltammetry from $0 \mathrm{~V}$ to $-1 \mathrm{~V}$ at $0.2 \mathrm{~V} \mathrm{~s}^{-1}$. For the covalent immobilization of GSH via carbodiimide coupling, $10 \mu \mathrm{L}$ of a $35 \mathrm{mmol} \mathrm{L}^{-1}$ sulfo-NHS and $26 \mathrm{mmol} \mathrm{L}^{-1}$ 
EDC solution in $0.1 \mathrm{~mol} \mathrm{~L}^{-1}$ MES buffer ( $\mathrm{pH} 4.5$ ) were dropped onto the functionalized SPE and left for $1 \mathrm{~h}$. Finally, the activated carboxyl groups reacted overnight with the amine terminal groups of GSH (2.9 mg/100 $\mu \mathrm{L}$ GSH solution in MES buffer) at $4{ }^{\circ} \mathrm{C}$.

This methodology was previously tested showing a very high repetitivity and reproducibility[35].

2.3.4. Cysteine modified electrode (Cys-SPCE-CNF): Cys was immobilized on aryl diazonium salt monolayers anchored to the surface of SPCE-CNF. For the preparation of the Cys-SPCE-CNF the GSH-SPCE-CNF above mentioned procedure was implemented, using Cys instead of GSH.

\subsection{Voltammetric measurements.}

Stripping voltammetric (DPASV) measurements using SPCE-CNF, ex-situ-SbSPCECNF, GSH-SPCE-CNF and Cys-SPCE-CNF were performed by applying with stirring a deposition potential $\left(\mathrm{E}_{\mathrm{d}}\right)$ of $-1.4 \mathrm{~V}$ during a deposition time $\left(\mathrm{t}_{\mathrm{d}}\right)$ of $120 \mathrm{~s}$ followed by a rest period $\left(\mathrm{t}_{\mathrm{r}}\right)$ of $5 \mathrm{~s}$. Voltammograms were obtained by scanning the potential from 1.4 to $-0.3 \mathrm{~V}$, using a step potential of $5 \mathrm{mV}$, pulse amplitudes of $50 \mathrm{mV}$ and pulse times of $50 \mathrm{~ms}$.

In order to eliminate the remaining bound metals from the electrodes a cleaning step was performed between measurements by applying a conditioning potential $\left(\mathrm{E}_{\mathrm{cond}}\right)$ of $0.3 \mathrm{~V}$ for $15 \mathrm{~s}$ in $0.1 \mathrm{~mol} \mathrm{~L}^{-1} \mathrm{HClO}_{4}$ for ex-situ-SbSPCE-CNF, GSH-SPCE-CNF and Cys-SPCE-CNF electrodes and $0 \mathrm{~V}$ for $15 \mathrm{~s}$ in $0.1 \mathrm{~mol} \mathrm{~L}^{-1} \mathrm{HNO}_{3}$ for SPCE-CNF electrode. On the other hand, the array of electrodes was completely replaced by a new set every 20 measurements to ensure their optimal performance. 
Linear calibration plots for the separate determination of considered metal ions were obtained by increasing metal ion concentrations in $0.1 \mathrm{~mol} \mathrm{~L}^{-1}$ acetate buffer solution at $\mathrm{pH} 4.5$.

In order to allow the simultaneous analysis of $\mathrm{Zn}(\mathrm{II}), \mathrm{Cd}(\mathrm{II}), \mathrm{Pb}(\mathrm{II}), \mathrm{Tl}(\mathrm{I}), \mathrm{In}(\mathrm{III})$ and $\mathrm{Bi}(\mathrm{III})$ a total set of 57 samples ranging from 0 to $200 \mu \mathrm{g} \mathrm{\textrm {L } ^ { - 1 }}$ were prepared from appropriate dilution of stock solutions. The total set of samples was distributed among training and test subsets. The training subset was formed by 45 samples $(79 \%)$ distributed in a 6 factor central composite design whereas the test subset was formed by 12 samples $(21 \%)$ located in the centre of the cubes faces (Figure 2a). In addition, control samples (replicates of the central point of the experimental design) were inserted every 10 measurements.

Furthermore, 3 replicates of a spiked tap water sample with the six considered metal ions distributed in the range of the calibration curve were employed to test the suitability of the four-sensor array for the analysis of $\mathrm{Zn}(\mathrm{II}), \mathrm{Cd}(\mathrm{II}), \mathrm{Pb}(\mathrm{II}), \mathrm{Tl}(\mathrm{I}), \mathrm{In}(\mathrm{III})$ and $\mathrm{Bi}(\mathrm{III})$ in natural samples.

\subsection{Sample preparation.}

Water samples collected from the local water distribution network were firstly acidified (pH 4.5) and then spiked with $70 \mu \mathrm{g} \mathrm{L}{ }^{-1}$ of $\mathrm{Zn}(\mathrm{II}), \mathrm{In}(\mathrm{III})$ and $\mathrm{Bi}(\mathrm{III}), 80 \mu \mathrm{g} \mathrm{\textrm {L } ^ { - 1 }}$ of $\mathrm{Cd}(\mathrm{II})$ and $\mathrm{Tl}(\mathrm{III})$ and $90 \mu \mathrm{g} \mathrm{\textrm {L } ^ { - 1 }}$ of $\mathrm{Pb}(\mathrm{II})$. Total metal ion concentrations were further determined by ICP-MS. 


\subsection{Data processing.}

Prior to building the PLS model a preprocessing step was performed on each voltammogram. With this purpose, an orthogonal signal correction (OSC) [37] was performed in order to remove variations to the data that are not relevant to the model (noise, baseline...). OSC was performed on calibration data and then applied to the validation data and natural samples data.

In order to reduce the large amount of data generated for each sample (4 sensors x 555 current values) a hierarchical model was considered [38]. In this sense, the data set was separated in 4 blocks corresponding to the 4 sensors and PLS was performed on each block. Scores values obtained for each block were used as new descriptors and PLS was performed again (Figure 2b).

Pre-processing of the data matrices, variable selection and construction of PLS model were made using Matlab ${ }^{\circledR}[39]$ with PLS-toolbox[40].

\section{RESULTS AND DISCUSSION}

\subsection{Voltammetric calibration data.}

Firstly, individual calibration of $\mathrm{Zn}(\mathrm{II}), \mathrm{Cd}(\mathrm{II}), \mathrm{Pb}(\mathrm{II}), \mathrm{Tl}(\mathrm{I}), \mathrm{In}(\mathrm{III})$ and $\mathrm{Bi}(\mathrm{III})$ ions by DPASV was carried out on each SPCE-CNF, ex-situ-SbSPCE-CNF, GSH-SPCE-CNF and Cys-SPCE-CNF respectively. The optimized application $[25,34,35]$ of an $E_{d}$ of -1.4 $\mathrm{V}$ with stirring during a $t_{d}$ of $120 \mathrm{~s}$ followed by a $t_{\mathrm{r}}$ of $5 \mathrm{~s}$ without stirring allows, at each of the four electrodes, the determination of all metal ions in the considered concentration range. In order to build the calibration curves, ten standard concentrations of the considered metal ions were used. Comparable voltammetric responses for $\mathrm{Zn}(\mathrm{II})$, $\mathrm{Cd}(\mathrm{II}), \mathrm{Pb}(\mathrm{II}), \mathrm{Tl}(\mathrm{I}), \mathrm{In}(\mathrm{III})$ and $\mathrm{Bi}(\mathrm{III})$ were obtained using SPCE-CNF, ex-situ- 
SbSPCE-CNF, GSH-SPCE-CNF and Cys-SPCE-CNF at identical experimental conditions. Figure 3 shows, as an example, the individual voltammetric responses obtained for each metal ion on SPCE-CNF. Table 1 summarizes the sensitivities calculated from the slope of the calibration lines of each metal ion at the four modified SPEs and the correlation coefficients, as well as the limits of detection (LOD) considered as 3 times the standard deviation of the intercept over the slope of the calibration curve of the target ions, and the limits of quantification (LOQ) calculated as 10 times the previous ratio for all six metals. It should be pointed out that LOQ was designed as the lowest value of the linear concentration range. Very good linear responses of the peak area vs. concentration were achieved for $\mathrm{Zn}(\mathrm{II}), \mathrm{Cd}(\mathrm{II}), \mathrm{Pb}(\mathrm{II})$, $\mathrm{Tl}(\mathrm{I}), \mathrm{In}(\mathrm{III})$ and $\mathrm{Bi}(\mathrm{III})$ until a concentration level close to $200 \mu \mathrm{g} \mathrm{L}^{-1}$ for all considered metal ions at the four modified SPEs. Regarding the obtained sensitivities it can be stated that: i) using SPCE-CNF, Cd(II) was the metal ion presenting better sensitivity; ii) $\mathrm{Pb}$ (II) was the most sensitive metal using both GSH-SPCE-CNF and Cys-SPCECNF; iii) using ex-situ-SbSPCE-CNF, Cd(II) and also Zn(II) showed better sensitivity; and iv) the best sensitivity for In(III) and Bi(III) were achieved on SPCE-CNF. The LODs of the six metal ions in the four modified SPEs ranged from 2.6 to $16.8 \mu \mathrm{g} \mathrm{L}^{-1}$ depending on both the metal ion and the modified SPE (Table 1) and the LOQ varied from 8.7 to $56.1 \mu \mathrm{g} \mathrm{L}^{-1}$ depending again on both the metal ion and the modified SPE (Table 1). These LODs and LOQs values are on the same order than previous reported modified electrodes $[26,27,29,35]$.

Moreover, taking into account the guidelines for drinking water quality [41], the proposed sensors seem to be perfectly suitable for the detection of heavy metals ions in environmental water. 
Therefore, the obtained calibration data indicate that the four modified SPEs could be completely appropriate for the analysis of $\mathrm{Zn}(\mathrm{II}), \mathrm{Cd}(\mathrm{II}), \mathrm{Pb}(\mathrm{II}), \mathrm{Tl}(\mathrm{I}), \mathrm{In}(\mathrm{III})$ and $\mathrm{Bi}(\mathrm{III})$ at trace levels in environmental samples. Moreover, the cross-response of the selected sensors was stated. Thus, the use of the four modified SPEs as an electrode array configuration instead of as single sensors could introduce some discrimination power to elucidate a mixture of the different metal ions.

\subsection{Multimetal Stripping Voltammetric Measurements.}

The stripping voltammetric performance of several mixtures of $\mathrm{Zn}(\mathrm{II}), \mathrm{Cd}(\mathrm{II}), \mathrm{Pb}(\mathrm{II})$, $\mathrm{Tl}(\mathrm{I}), \mathrm{In}(\mathrm{III})$ and $\mathrm{Bi}(\mathrm{III})$ was studied using SPCE-CNF, ex-situ-SbSPCE-CNF, GSHSPCE-CNF and Cys-SPCE-CNF working as an electrode array inside the concentration range $0-200 \mu \mathrm{g} \mathrm{L}^{-1}$ to identify potential interactions between the considered metal ions. As an example, Figure 4a shows four stripping voltammograms recorded using ex-situSbSPCE-CNF (random concentrations). Complex voltammograms with an important overlapping effect were observed hindering not only the straight determination of the different metals of the mixture but also the direct assignment of the oxidation peak potential of each considered metal in the intricate voltammograms. Nevertheless, from separate metal stripping measurements and in general terms, the overlapped peaks from $-1.4 \mathrm{~V}$ to $-0.9 \mathrm{~V}$ could be attributed to $\mathrm{Zn}(\mathrm{II}), \mathrm{Cd}(\mathrm{II})$ and $\mathrm{Tl}(\mathrm{I})$ whereas the peaks related to $\mathrm{Pb}(\mathrm{II})$ and $\mathrm{In}(\mathrm{III})$ would be those shown from $-0.9 \mathrm{~V}$ to $-0.55 \mathrm{~V}$ and finally the peak close to $-0.4 \mathrm{~V}$ would be assigned to $\mathrm{Bi}(\mathrm{III})$. Figure $4 \mathrm{~b}$ shows, as an example, a comparison of the stripping voltammograms of $100 \mu \mathrm{g} \mathrm{L}^{-1} \mathrm{Zn}(\mathrm{II}), \mathrm{Cd}(\mathrm{II}), \mathrm{Tl}(\mathrm{I}), \mathrm{Pb}(\mathrm{II})$, In(III) and Bi(III) provided by Cys-SPCE-CNF (thin line), ex-situ-SbSPCE-CNF (dashed thin line), GSH-SPCE-CNF (dashed thick line) and SPCE-CNF (thick line). Some significant differences in metal peak potentials and shapes can be clearly 
perceived in the stripping voltammetric response of the sensor array depending on both the metal ion and the modified SPE used. This fact confirms that the information provided by the electrode array is significantly better than that obtained from a single electrode. Thus, despite the intricate signal origin, in a next step, the voltammetric data set of metal ion mixtures provided by the sensor array will be proposed to be used to calibrate $\mathrm{Zn}(\mathrm{II}), \mathrm{Cd}(\mathrm{II}), \mathrm{Tl}(\mathrm{I}), \mathrm{Pb}(\mathrm{II}), \mathrm{In}(\mathrm{III})$ and $\mathrm{Bi}(\mathrm{III})$ with a suitable PLS model that may consider any overlapping to assist us in the better determination of the studied metal ions.

\subsection{Calibration and validation of PLS model in metal mixtures.}

For the voltammetric electronic tongue study a total set of 57 metal mixtures samples (45 corresponding to the training set and 12 to the test set) with concentrations ranging from 0 to $200 \mu \mathrm{g} \mathrm{L} \mathrm{L}^{-1}$ were prepared and voltammetric stripping measurements were performed simultaneously on SPCE-CNF, ex-situ-SbSPCE-CNF, GSH-SPCE-CNF and Cys-SPCE-CNF. It should be pointed out that, although it has already been proven that these electrodes can be used for a large set of measurements [35,36], to ensure the optimal performance of the sensor array, all the electrodes were replaced every 20 measurements. In addition, due to the large amount of samples considered, the measurements were carried out in two consecutive days. However, control samples inserted between measurements corroborate the use of different electrode units in different days does not affect the voltammetric stripping response.

Prior to building the PLS models, each sensor signal was processed by OSC (1 component determined by the amount of Y block variance explained by the first latent variable) and the resulting data were mean centred. The effect of OSC is that undesired 
variations of experimental data (eg, noise, baseline) are removed from the signal whereas variance attributed to target ions is retained. Because of the large amount of information generated (4 voltammograms for each sample), a hierarchical model was considered. In this sense, PLS-2 was performed on each working electrode processed signal, score values were combined in a new data matrix and PLS was performed again, but now in the modality of PLS-1 (Figure 2b).

As it was previously mentioned, $\mathrm{Zn}(\mathrm{II}), \mathrm{Cd}(\mathrm{II})$ and $\mathrm{Tl}(\mathrm{I})$ peaks are overlapped in the left side of the voltammogram (from $-1.4 \mathrm{~V}$ to $-0.9 \mathrm{~V}$ ) whereas $\mathrm{Pb}$ (II) and $\mathrm{In}(\mathrm{III})$ peaks appear from $-0.9 \mathrm{~V}$ to $-0.55 \mathrm{~V}$ and $\mathrm{Bi}(\mathrm{III})$ corresponds to the peak near $-0.4 \mathrm{~V}$. For this reason, although individual models were performed for each metal, PLS-2 models considering only $\mathrm{Zn}(\mathrm{II}), \mathrm{Cd}(\mathrm{II})$ and $\mathrm{Tl}(\mathrm{I})$, only $\mathrm{Pb}(\mathrm{II})$ and $\mathrm{In}(\mathrm{III})$ or only $\mathrm{Bi}(\mathrm{III})$ were performed on each sensor. The number of latent variables, pre-established by crossvalidation (venetian blinds method), was selected considering the predictive ability for each metal ion separately and varied from 1 to 6 in the hierarchical step and from 2 to 3 in the final step depending on the considered metal.

Another important aspect to be considered is the number of electrodes to be used in each PLS model. In this sense, it was observed that adding two electrodes with similar sensitivities to the model increases the number of variables, and therefore the complexity of the model, but does not improve its performance. The electrodes used in the PLS model built for each metal are shown in Table 2. It should be pointed out that the inclusion of samples measured in different days on different units does not influence the building of the PLS model.

Good PLS models were obtained for $\mathrm{Pb}(\mathrm{II}), \mathrm{Cd}(\mathrm{II}), \mathrm{Tl}(\mathrm{I})$ and $\mathrm{Bi}(\mathrm{III})$ but not for $\mathrm{In}(\mathrm{III})$ and $\mathrm{Zn}(\mathrm{II})$. However, the presence of these metals in the sample does not hinder the calibration of PLS models for $\mathrm{Pb}(\mathrm{II}), \mathrm{Cd}(\mathrm{II}), \mathrm{Tl}(\mathrm{I})$ and $\mathrm{Bi}(\mathrm{III})$. The global performance 
of the models built is shown in Figure 5 and Table 3. As it can be seen, calibration curves are close to the ideal one, with slopes and correlation values close to 1 and intercept values close to 0 . Root mean square errors (RMSE) for calibration were also calculated and are shown in Table 3.

The predictive ability of each model was evaluated with the test subset. As it can be seen in the comparison graphs of predicted vs. expected concentration (Figure 5), test samples (white symbols) are always in the variation range defined by the training set (black symbols). RMSE for prediction, 6.64 for $\mathrm{Pb}(\mathrm{II}), 11.01$ for $\mathrm{Cd}(\mathrm{II}), 8.71$ for $\mathrm{Tl}(\mathrm{I})$ and 14.8 for $\mathrm{Bi}(\mathrm{III})$, were all comparable to those obtained for calibration. It should be pointed out that, despite of the increased complexity of the considered system (4 analytes and 2 interferences), the obtained RMSEs values for prediction are similar to those reported by previous voltammetric electronic tongues for metal ions determination [22-25].

These results suggest that the combination of SPCE-CNF, ex-situ-SbSPCE-CNF, GSHSPCE-CNF and Cys-SPCE-CNF as a sensor array could be used for the simultaneous determination of $\mathrm{Cd}(\mathrm{II}), \mathrm{Pb}(\mathrm{II}), \mathrm{Tl}(\mathrm{I})$ and $\mathrm{Bi}(\mathrm{III})$ in the presence of $\mathrm{Zn}(\mathrm{II})$ and $\mathrm{In}(\mathrm{III})$ in natural samples.

\subsection{Application to the analysis of real samples.}

At the view of the above results, a sensor array formed by SPCE-CNF, ex-situ-SbSPCECNF, GSH-SPCE-CNF and Cys-SPCE-CNF was considered for the determination of $\mathrm{Cd}(\mathrm{II}), \mathrm{Pb}(\mathrm{II}), \mathrm{Tl}(\mathrm{I})$ and $\mathrm{Bi}(\mathrm{III})$ in the presence of $\mathrm{Zn}(\mathrm{II})$ and $\mathrm{In}(\mathrm{III})$ in real samples and its applicability was tested on a spiked tap water. Then, voltammetric stripping measurements of three replicates of the determination of the tap water by means of the 
electronic tongue were carried out in the above mentioned conditions and voltammetric signals that behave equally to the training and test sets were obtained.

$\mathrm{Cd}(\mathrm{II}), \mathrm{Pb}(\mathrm{II}), \mathrm{Tl}(\mathrm{I})$ and $\mathrm{Bi}(\mathrm{III})$ concentrations were calculated from the previously calibrated PLS models. A good concordance of all metal ion concentrations between all replicates inferred by the obtained $\operatorname{RSD}(\%)$ (Table 4) was achieved, especially in the case of $\mathrm{Cd}(\mathrm{II})$ and $\mathrm{Pb}(\mathrm{II})$. The obtained results, shown in Table 4, were also compared to those obtained by ICP-MS. In order to evaluate the agreement between each metal ion concentration obtained from both techniques, a two-tailed t-test (equal variances) was performed for each sample and it was concluded that the results obtained by the electronic tongue and ICP-MS were statistically similar for a confidence level of $95 \%$. Therefore, these good results confirm the applicability of the combination of SPCECNF, ex-situ-SbSPCE-CNF, GSH-SPCE-CNF and Cys-SPCE-CNF in a sensor array with a suitable PLS model for the simultaneous determination of $\mathrm{Cd}(\mathrm{II}), \mathrm{Pb}(\mathrm{II}), \mathrm{Tl}(\mathrm{I})$ and $\mathrm{Bi}(\mathrm{III})$ in the presence of $\mathrm{Zn}(\mathrm{II})$ and $\mathrm{In}(\mathrm{III})$ in real samples, being an interesting and cheaper alternative to more conventional techniques such as ICP-MS.

\section{CONCLUSIONS}

In this work, a voltammetric electronic tongue based completely on screen-printed electrodes has been successfully applied for the first time for the analysis of a complex mixture of metal ions in natural samples (4 analytes in the presence of 2 interferences). This electronic tongue was constituted by four sensors that have been modified following different strategies: SPCE-CNF, ex-situ-SbSPCE-CNF, GSH-SPCE-CNF and Cys-SPCE-CNF.

Firstly, the voltammetric performance of each metal on each electrode was studied and a cross-response between them was stated. Although the voltammetric response of the 
metal mixture of each sensor is very complex due to the presence of overlapped signals, the combination of the four modified SPEs as an electrode array configuration instead of as single sensors introduces some discrimination power that allows to elucidate the mixture of the considered metal ions. In this sense, in the present study, the simultaneous quantification of $\mathrm{Cd}(\mathrm{II}), \mathrm{Pb}(\mathrm{II}), \mathrm{Tl}(\mathrm{I})$ and $\mathrm{Bi}(\mathrm{III})$ in the presence of $\mathrm{Zn}$ (II) and In(III) was successfully carried out by combining the voltammetric responses from the four electrodes with chemometric tools. Hence, obtained DPASV data were processed by a PLS model that was built considering a hierarchical model in order to

reduce the large amount of data. Good results, both for training and testing, inferred by correlation coefficients evaluated from predicted vs. expected concentrations were obtained. Moreover, the simultaneous determination of $\mathrm{Cd}(\mathrm{II}), \mathrm{Pb}(\mathrm{II}), \mathrm{Tl}(\mathrm{I})$ and $\mathrm{Bi}(\mathrm{III})$ in the presence of $\mathrm{Zn}(\mathrm{II})$ and $\mathrm{In}(\mathrm{III})$ in an spiked tap water was also satisfactory achieved, providing comparable results to those obtained by ICP-MS.

The reported results demonstrate that the use of the presented sensor array combined with the construction of an appropriate PLS model is suitable for the simultaneous quantification of $\mathrm{Cd}(\mathrm{II}), \mathrm{Pb}(\mathrm{II}), \mathrm{Tl}(\mathrm{I})$ and $\mathrm{Bi}(\mathrm{III})$ in the presence of $\mathrm{Zn}(\mathrm{II})$ and $\mathrm{In}(\mathrm{III})$ in environmental samples.

\section{AKNOWLEDGMENTS}

This work is supported by the Generalitat of Catalonia (Project 2014SGR269). Clara Pérez-Ràfols acknowledges the Spanish Ministry of Economy and Competitiveness for a Ph.D grant.

\section{REFERENCES}

[1] I.D.L. Foster, S.M. Charlesworth, Heavy metals in the hydrological cycle: trends 
and explanation, Hydrol. Process. 10 (1996) 227-261.

[2] J. Barek, J. Zima, Eighty years of polarography-history and future, Electroanalysis. 15 $467-472$. http://onlinelibrary.wiley.com/doi/10.1002/elan.200390055/abstract.

[3] M.I. Castro-González, M. Méndez-Armenta, Heavy metals: Implications associated to fish consumption, Environ. Toxicol. Pharmacol. 26 (2008) 263271. doi:10.1016/j.etap.2008.06.001.

[4] J. Baby, J.S. Raj, E.T. Biby, P. Sankarganesh, M. V. Jeevitha, S.U. Ajisha, et al., Toxic effect of heavy metals on aquatic environment, Int. J. Biol. Chem. Sci. 4 (2010) 939-952. doi:10.1111/j.1439-0507.2010.01876.x.

[5] S.E. Jorgensen, B. Fath, Encyclopedia of Ecology, Volume 1, Newnes, 2008.

[6] D. Mendil, Ö.F. Ünal, M. Tüzen, M. Soylak, Determination of trace metals in different fish species and sediments from the River Yeşilirmak in Tokat, Turkey, Food Chem. Toxicol. 48 (2010) 1383-1392. doi:10.1016/j.fct.2010.03.006.

[7] H. Sereshti, Y. Entezari Heravi, S. Samadi, Optimized ultrasound-assisted emulsification microextraction for simultaneous trace multielement determination of heavy metals in real water samples by ICP-OES, Talanta. 97 (2012) 235-241. doi:10.1016/j.talanta.2012.04.024.

[8] B. Dai, M. Cao, G. Fang, B. Liu, X. Dong, M. Pan, et al., Schiff base-chitosan grafted multiwal led carbon nanotubes as a novel solid-phase extraction adsorbent for determination of heavy metal by ICP-MS, J. Hazard. Mater. 219220 (2012) 103-110. doi:10.1016/j.jhazmat.2012.03.065.

[9] J. Wang, Stripping analysis: Principles, instrumentation and applications, VCH, Deerfield Beach, FL, 1985.

[10] I. Šinko, J. Doleal, Simultaneous determination of copper, cadmium, lead and 
zinc in water by anodic stripping polarography, J. Electroanal. Chem. Interfacial Electrochem. 25 (1970) 299-306.

[11] S. Das, V. Kumar, M. Gupta, N. Singh, S.S. Assistant, N. Delhi, Simultaneous Determination of Zinc ( $\mathrm{Zn}$ ), Cadmium ( $\mathrm{Cd}$ ), Lead ( $\mathrm{Pb}$ ) and Copper ( $\mathrm{Cu}$ ) in Blood Using Differential- Pulse Anodic-Stripping Voltammetry, Int. J. Eng. Res. 4 (2015) 235-239.

[12] M. del Valle, Sensor arrays and electronic tongue systems, Int. J. Electrochem. 2012 (2012) 1-12. doi:10.1155/2012/986025.

[13] J. Zeravik, A. Hlavacek, K. Lacina, P. Skládal, State of the art in the field of electronic and bioelectronic tongues - towards the analysis of wines, Electroanalysis. 21 (2009) 2509-2520. doi:10.1002/elan.200900285.

[14] P. Ciosek, W. Wróblewski, Sensor arrays for liquid sensing--electronic tongue systems., Analyst. 132 (2007) 963-978. doi:10.1039/b705107g.

[15] X. Cetó, N.H. Voelcker, B. Prieto-Simón, Bioelectronic tongues: New trends and applications in water and food analysis, Biosens. Bioelectron. 79 (2016) 608626. doi:10.1016/j.bios.2015.12.075.

[16] M. Esteban, C. Ariño, J.M. Díaz-Cruz, Chemometrics for the analysis of voltammetric data, TrAC - Trends Anal. Chem. 25 (2006) 86-92. doi:10.1016/j.trac.2005.07.009.

[17] X. Cetó, F. Céspedes, M. del Valle, Comparison of methods for the processing of voltammetric electronic tongues data, Microchim. Acta. 180 (2013) 319-330. doi:10.1007/s00604-012-0938-7.

[18] Y. Tahara, K. Toko, Electronic Tongues - A Review, IEEE Sens. J. 13 (2013) $3001-3011$.

[19] M. del Valle, Electronic tongues employing electrochemical sensors, 
Electroanalysis. 22 (2010) 1539-1555. doi:10.1002/elan.201000013.

[20] F. Winquist, Voltammetric electronic tongues - Basic principles and applications, Microchim. Acta. 163 (2008) 3-10. doi:10.1007/s00604-007-0929-2.

[21] A. Gutés, F. Céspedes, M. del Valle, Electronic tongues in flow analysis, Anal. Chim. Acta. 600 (2007) 90-96. doi:10.1016/j.aca.2007.03.039.

[22] N. Serrano, B. Prieto-Simón, X. Cetó, M. del Valle, Array of peptide-modified electrodes for the simultaneous determination of $\mathrm{Pb}(\mathrm{II}), \mathrm{Cd}(\mathrm{II})$ and $\mathrm{Zn}(\mathrm{II})$, Talanta. 125 (2014) 159-166. doi:10.1016/j.talanta.2014.02.052.

[23] N. Serrano, A. González-Calabuig, M. del Valle, Crown ether-modified electrodes for the simultaneous stripping voltammetric determination of $\mathrm{Cd}(\mathrm{II})$, $\mathrm{Pb}(\mathrm{II}) \quad$ and $\quad \mathrm{Cu}(\mathrm{II}), \quad$ Talanta. $138 \quad$ (2015) 130-137. doi:10.1016/j.talanta.2015.01.044.

[24] A. González-Calabuig, D. Guerrero, N. Serrano, M. del Valle, Simultaneous voltammetric determination of heavy metals by use of crown ether-modified electrodes and chemometrics, Electroanalysis. 28 (2016) 663-670. doi:10.1002/elan.201500512.

[25] C. Pérez-Ràfols, N. Serrano, J.M. Díaz-Cruz, C. Ariño, M. Esteban, Simultaneous determination of $\mathrm{Tl}(\mathrm{I})$ and $\mathrm{In}(\mathrm{III})$ using a voltammetric sensor array, Sensors Actuators B Chem. $245 \quad$ (2017) 18-24. doi:10.1016/j.snb.2017.01.089.

[26] N. Serrano, A. Alberich, J.M. Díaz-Cruz, C. Ariño, M. Esteban, Coating methods, modifiers and applications of bismuth screen-printed electrodes, TrAC Trends Anal. Chem. 46 (2013) 15-29. doi:10.1016/j.trac.2013.01.012.

[27] N. Serrano, J.M. Díaz-Cruz, C. Ariño, M. Esteban, Antimony- based electrodes for analytical determinations, TrAC Trends Anal. Chem. 77 (2016) 203-213. 
doi:10.1016/j.trac.2016.01.011.

[28] D. Bélanger, J. Pinson, Electrografting: a powerful method for surface modification., Chem. Soc. Rev. 40 (2011) 3995-4048. doi:10.1039/c0cs00149j.

[29] J. Barton, M.B.G. García, D.H. Santos, P. Fanjul-Bolado, A. Ribotti, M. McCaul, et al., Screen-printed electrodes for environmental monitoring of heavy metal ions: a review, Microchim. Acta. 183 (2016) 503-517. doi:10.1007/s00604-015$1651-0$.

[30] M. Li, Y.T. Li, D.W. Li, Y.T. Long, Recent developments and applications of screen-printed electrodes in environmental assays-A review, Anal. Chim. Acta. 734 (2012) 31-44. doi:10.1016/j.aca.2012.05.018.

[31] J.P. Metters, R.O. Kadara, C.E. Banks, New directions in screen printed electroanalytical sensors: an overview of recent developments., Analyst. 136 (2011) 1067-1076. doi:10.1039/c0an00894j.

[32] O.D. Renedo, M.A. Alonso-Lomillo, M.J.A. Martínez, Recent developments in the field of screen-printed electrodes and their related applications, Talanta. 73 (2007) 202-219. doi:10.1016/j.talanta.2007.03.050.

[33] K. Duarte, C.I.L. Justino, A.C. Freitas, A.M.P. Gomes, A.C. Duarte, T.A.P. Rocha-Santos, Disposable sensors for environmental monitoring of lead, cadmium and mercury, TrAC - Trends Anal. Chem. 64 (2015) 183-190. doi:10.1016/j.trac.2014.07.006.

[34] C. Pérez-Ràfols, N. Serrano, J.M. Díaz-cruz, C. Ariño, M. Esteban, New approaches to antimony film screen-printed electrodes using carbon-based nanomaterials substrates, Anal. Chim. Acta. $916 \quad$ (2016) 17-23. doi:10.1016/j.aca.2016.03.003.

[35] C. Pérez-Ràfols, N. Serrano, J.M. Díaz-Cruz, C. Ariño, M. Esteban, Glutathione 
modified screen-printed carbon nanofiber electrode for the voltammetric determination of metal ions in natural samples, Talanta. 155 (2016) 8-13. doi:10.1016/j.talanta.2016.04.011.

[36] C. Barceló, N. Serrano, C. Ariño, J.M. Díaz-Cruz, M. Esteban, Ex-situ antimony screen-printed carbon electrode for voltammetric determination of $\mathrm{Ni}$ (II)-ions in wastewater, Electroanalysis. 28 (2016) 640-644. doi:10.1002/elan.201500511.

[37] S. Wold, H. Antti, F. Lindgren, J. Öhman, Orthogonal signal correction of nearinfrared spectra, Chemom. Intell. Lab. Syst. 44 (1998) 175-185.

[38] S. Wold, J. Trygg, A. Berglund, H. Antti, Some recent developments in PLS modeling, Chemom. Intell. Lab. Syst. 51 (2001) 131-150.

[39] Matlab, version R2008b ed., Mathworks Inc.: Natick, MA, USA, (2008).

[40] PLS-toolbox version 7.8.2 (Eigenvector Research Inc., Wenatchee, USA).

[41] Guidelines for Drinking-water Quality -- 4th ed,World Health Organization, Geneva, Switzerland, (2011). 
Table 1. Calibration data for the separate determination of $\mathrm{Zn}(\mathrm{II}), \mathrm{Cd}(\mathrm{II}), \mathrm{Pb}(\mathrm{II}), \mathrm{Bi}(\mathrm{III}), \mathrm{In}(\mathrm{III})$ and $\mathrm{Tl}(\mathrm{I})$ on the multisensor array formed by SPCE-CNF/ GSH-SPCE-CNF/ Cys-SPCE-CNF/ Ex-situ-SbSPCE-CNF modified electrodes at E $\mathrm{d}_{\mathrm{d}}$ of -1.4 V using a $\mathrm{t}_{\mathrm{d}}$ of $120 \mathrm{~s}$ at $\mathrm{pH} 4.5$.

\begin{tabular}{|c|c|c|c|c|c|c|}
\hline & $\mathrm{Zn}(\mathrm{II})$ & Cd(II) & $\mathrm{Pb}(\mathrm{II})$ & Bi(III) & In(III) & $\mathbf{T l}(\mathbf{I})$ \\
\hline \multicolumn{7}{|l|}{ SPCE-CNF } \\
\hline Sensitivity (a.u. $\mu \mathrm{g}^{-1} \mathrm{~L}$ ) & $3.75(0.06)$ & $5.45(0.05)$ & $4.59(0.03)$ & $0.40(0.01)$ & $2.80(0.03)$ & $2.73(0.03)$ \\
\hline $\mathrm{R}^{2}$ & 0.999 & 0.999 & 0.999 & 0.996 & 0.999 & 0.999 \\
\hline Linear range $^{\mathrm{a}}\left(\mu \mathrm{g} \mathrm{L}^{-1}\right)$ & $16.9-198.3$ & $11.3-200.0$ & $8.7-200.8$ & $56.1-200.7$ & $10.0-200.4$ & $21.7-274.9$ \\
\hline $\operatorname{LOD}\left(\mu \mathrm{g} \mathrm{L}^{-1}\right)$ & 5.1 & 3.4 & 2.6 & 16.8 & 3.0 & 6.5 \\
\hline \multicolumn{7}{|l|}{ GSH-SPCE-CNF } \\
\hline Sensitivity (a.u. $\left.\mu \mathrm{g}^{-1} \mathrm{~L}\right)$ & $1.71(0.04)$ & $0.62(0.01)$ & $3.27(0.03)$ & $0.240(0.005)$ & $0.47(0.01)$ & $0.97(0.02)$ \\
\hline $\mathrm{R}^{2}$ & 0.998 & 0.999 & 0.999 & 0.998 & 0.998 & 0.998 \\
\hline Linear range $^{\mathrm{a}}\left(\mu \mathrm{g} \mathrm{L}^{-1}\right)$ & $24.5-198.3$ & $11.6-200.0$ & $10.8-200.8$ & $29.1-200.7$ & $26.4-200.4$ & $41.8-274.9$ \\
\hline $\operatorname{LOD}\left(\mu \mathrm{g} \mathrm{L}^{-1}\right)$ & 7.4 & 3.5 & 3.2 & 8.7 & 7.9 & 12.5 \\
\hline \multicolumn{7}{|l|}{ Cys-SPCE-CNF } \\
\hline Sensitivity (a.u. $\mu \mathrm{g}^{-1} \mathrm{~L}$ ) & $2.19(0.05)$ & $1.43(0.01)$ & $3.48(0.03)$ & $0.196(0.005)$ & $0.277(0.004)$ & $1.08(0.03)$ \\
\hline $\mathrm{R}^{2}$ & 0.997 & 0.999 & 0.999 & 0.998 & 0.999 & 0.998 \\
\hline Linear range $^{\mathrm{a}}\left(\mu \mathrm{g} \mathrm{L}^{-1}\right)$ & $26.3-198.3$ & $10.9-200.0$ & $10.3-200.8$ & $38.0-200.7$ & $18.2-200.4$ & $57.8-274.9$ \\
\hline $\operatorname{LOD}\left(\mu \mathrm{g} \mathrm{L}^{-1}\right)$ & 7.9 & 3.3 & 3.1 & 11.4 & 5.5 & 17.4 \\
\hline \multicolumn{7}{|l|}{ Ex-situ-SbSPCE-CNF } \\
\hline Sensitivity (a.u. $\left.\mu \mathrm{g}^{-1} \mathrm{~L}\right)$ & $2.26(0.03)$ & $2.42(0.02)$ & $0.85(0.01)$ & $0.157(0.002)$ & $0.75(0.01)$ & $1.10(0.02)$ \\
\hline $\mathrm{R}^{2}$ & 0.999 & 0.999 & 0.999 & 0.999 & 0.999 & 0.999 \\
\hline Linear range $^{\mathrm{a}}\left(\mu \mathrm{g} \mathrm{L}^{-1}\right)$ & $14.9-198.3$ & $10.7-200.0$ & $13.2-200.8$ & $17.2-200.7$ & $21.0-200.4$ & $28.5-274.9$ \\
\hline $\operatorname{LOD}\left(\mu \mathrm{g} \mathrm{L}^{-1}\right)$ & 4.5 & 3.2 & 4.0 & 5.2 & 6.3 & 8.6 \\
\hline
\end{tabular}

${ }^{\text {a }}$ The lowest value of the linear range was considered from LOQ 
Table 2. Selection of sensors used in the PLS model for each metal

\begin{tabular}{lcccc}
\hline & Cd(II) & Pb(II) & Tl(I) & Bi(III) \\
\hline SPCE-CNF & $\mathrm{x}$ & $\mathrm{x}$ & $\mathrm{x}$ & $\mathrm{x}$ \\
GSH-SPCE-CNF & $\mathrm{x}$ & & $\mathrm{x}$ & $\mathrm{x}$ \\
Cys-SPCE-CNF & $\mathrm{x}$ & $\mathrm{x}$ & & \\
Ex-situ-SbSPCE-CNF & $\mathrm{x}$ & $\mathrm{x}$ & & \\
\hline
\end{tabular}


Table 3. Main parameters obtained for the fitted regression lines for the comparison between predicted $v s$. expected values for the training subset of samples and the different metal ions (intervals calculated at the $95 \%$ confidence level).

\begin{tabular}{lcccc}
\hline Metal & Slope & Intercept $\left(\boldsymbol{\mu g} \mathbf{L ~}^{-\mathbf{1}}\right)$ & Correlation & RMSE $\left(\boldsymbol{\mu} \mathbf{~ L ~}^{\mathbf{1}}\right)$ \\
\hline $\mathrm{Cd}(\mathrm{II})$ & $0.90(0.05)$ & $10(5)$ & 0.951 & 12.1 \\
$\mathrm{~Pb}(\mathrm{II})$ & $0.93(0.04)$ & $8(4)$ & 0.931 & 10.7 \\
$\mathrm{Tl}(\mathrm{I})$ & $0.90(0.05)$ & $10(5)$ & 0.927 & 12.3 \\
$\mathrm{Bi}(\mathrm{III})$ & $0.92(0.04)$ & $8(4)$ & 0.949 & 11.8 \\
\hline
\end{tabular}

RMSE: root mean square error 
Table 4. Total concentrations of $\mathrm{Cd}(\mathrm{II}), \mathrm{Pb}$ (II), $\mathrm{Tl}(\mathrm{I})$ and $\mathrm{Bi}(\mathrm{III})$ determined in tap water samples by DPASV on the multisensor array formed by SPCE-CNF/ GSH-SPCE-CNF/ Cys-SPCE-CNF/ Ex-situ-SbSPCE-CNF modified electrodes and by ICP-MS.

\begin{tabular}{llcccc}
\hline & & $\mathbf{C d}(\mathbf{I I})$ & $\mathbf{P b}(\mathbf{I I})$ & $\mathbf{T l}(\mathbf{I})$ & $\mathbf{B i}(\mathbf{I I I})$ \\
\hline DPASV & $\mathrm{c}\left(\mu \mathrm{g} \mathrm{L}^{-1}\right)$ & 84.1 & 83.4 & 77.6 & 66.1 \\
& $\mathrm{RSD} \%)$ & 1.1 & 3.6 & 13.6 & 8.4 \\
ICP-MS & $\mathrm{c}\left(\mu \mathrm{g} \mathrm{L}^{-1}\right)$ & 84.2 & 89.6 & 76.3 & 66.4 \\
& $\mathrm{RSD} \%)$ & 0.6 & 0.6 & 0.6 & 0.4 \\
\hline
\end{tabular}

$\mathrm{n}=3$ for $\operatorname{RSD}(\%)$ 


\section{Caption to figures}

Figure 1. Experimental setup for simultaneous stripping voltammetric measurements with four different screen-printed electrodes. A) DRP-CAC connectors. B) Screenprinted electrodes. C) $\mathrm{Ag} / \mathrm{AgCl}$ reference electrode. D) Carbon auxiliary electrode.

Figure 2. a) Experimental design used for training (•) and testing (०) subsets. $M_{1}, M_{2}$ and $\mathrm{M}_{3}$ represent any possible combination of 3 metals among $\mathrm{Zn}(\mathrm{II}), \mathrm{Cd}(\mathrm{II}), \mathrm{Tl}(\mathrm{I})$, $\mathrm{Pb}(\mathrm{II}), \mathrm{In}(\mathrm{III})$ and $\mathrm{Bi}(\mathrm{III})$. b) Hierardichal PLS model performed on the data set obtained with the voltammetric electronic tongue. Scores values from each sensor are used as descriptors in a new data matrix, $\mathrm{M}$.

Figure 3. Individual DPASV voltammograms of a solution containing $120 \mu \mathrm{g} \mathrm{L}^{-1}$ of $\mathrm{Pb}(\mathrm{II}), \mathrm{Zn}(\mathrm{II}), \mathrm{Cd}(\mathrm{II}), \mathrm{Tl}(\mathrm{I}), \mathrm{In}(\mathrm{III})$ and $\mathrm{Bi}(\mathrm{III})$ recorded on SPCE-CNF applying a $\mathrm{E}_{\mathrm{d}}$ of $-1,4 \mathrm{~V}$ during $120 \mathrm{~s}$ at acetate buffer $\mathrm{pH} 4.5$.

Figure 4. a) DPASV voltammograms on ex-situ-SbSPCE-CNF and applying a $\mathrm{E}_{\mathrm{d}}$ of $-1,4 \mathrm{~V}$ during $120 \mathrm{~s}$ at acetate buffer $\mathrm{pH} 4.5$ of a solution containing $142 \mu \mathrm{g} \mathrm{L}^{-1} \mathrm{Zn}$ (II), $\mathrm{Pb}(\mathrm{II}), \mathrm{In}(\mathrm{III})$ and $\mathrm{Bi}(\mathrm{III})$ and $58 \mu \mathrm{g} \mathrm{L}^{-1} \mathrm{Cd}(\mathrm{II})$ and $\mathrm{Tl}(\mathrm{I})$ (thick line), $142 \mu \mathrm{g} \mathrm{L}^{-1} \mathrm{Cd}(\mathrm{II})$, $\mathrm{Tl}(\mathrm{I}), \mathrm{In}(\mathrm{III})$ and $\mathrm{Bi}(\mathrm{III})$ and $58 \mu \mathrm{g} \mathrm{L}^{-1} \mathrm{Zn}(\mathrm{II})$ and $\mathrm{Pb}$ (II) (thin line), $142 \mu \mathrm{g} \mathrm{L}^{-1} \mathrm{Zn}$ (II), In(III) and $58 \mu \mathrm{g} \mathrm{L}^{-1} \mathrm{Cd}(\mathrm{II}), \mathrm{Pb}(\mathrm{II}), \mathrm{Bi}(\mathrm{III})$ and $\mathrm{Tl}(\mathrm{I})$ (dashed thick line), $142 \mu \mathrm{g} \mathrm{L}^{-1} \mathrm{Tl}(\mathrm{I})$ and $\mathrm{In}(\mathrm{III})$ and $58 \mu \mathrm{g} \mathrm{L}^{-1} \mathrm{Zn}(\mathrm{II}), \mathrm{Cd}(\mathrm{II}), \mathrm{Pb}(\mathrm{II})$ and $\mathrm{Bi}(\mathrm{III})$ (dashed thin line). b) DPASV voltammograms of $100 \mu \mathrm{g} \mathrm{L}^{-1} \mathrm{Zn}(\mathrm{II}), \mathrm{Cd}(\mathrm{II}), \mathrm{Tl}(\mathrm{I}), \mathrm{Pb}(\mathrm{II}), \mathrm{In}(\mathrm{III})$ and $\mathrm{Bi}(\mathrm{III})$ on CysSPCE-CNF (thin line), ex-situ-SbSPCE-CNF (dashed thin line), GSH-SPCE-CNF (dashed thick line) and SPCE-CNF (thick line) applying a $E_{d}$ of $-1,4 \mathrm{~V}$ during $120 \mathrm{~s}$ at acetate buffer $\mathrm{pH} 4.5$. 
Figure 5. Comparison graphs of predicted $v s$. expected concentrations for a) $\mathrm{Pb}(\mathrm{II}), \mathrm{b}$ ) $\mathrm{Cd}(\mathrm{II})$, c) $\mathrm{Tl}(\mathrm{I})$ and d) $\mathrm{Bi}(\mathrm{III})$ for training set $(\bullet)$, test set $(\mathrm{O})$ and real samples $(\bullet)$.

Dashed line represents theoretical diagonal line $(\mathrm{y}=\mathrm{x})$. 


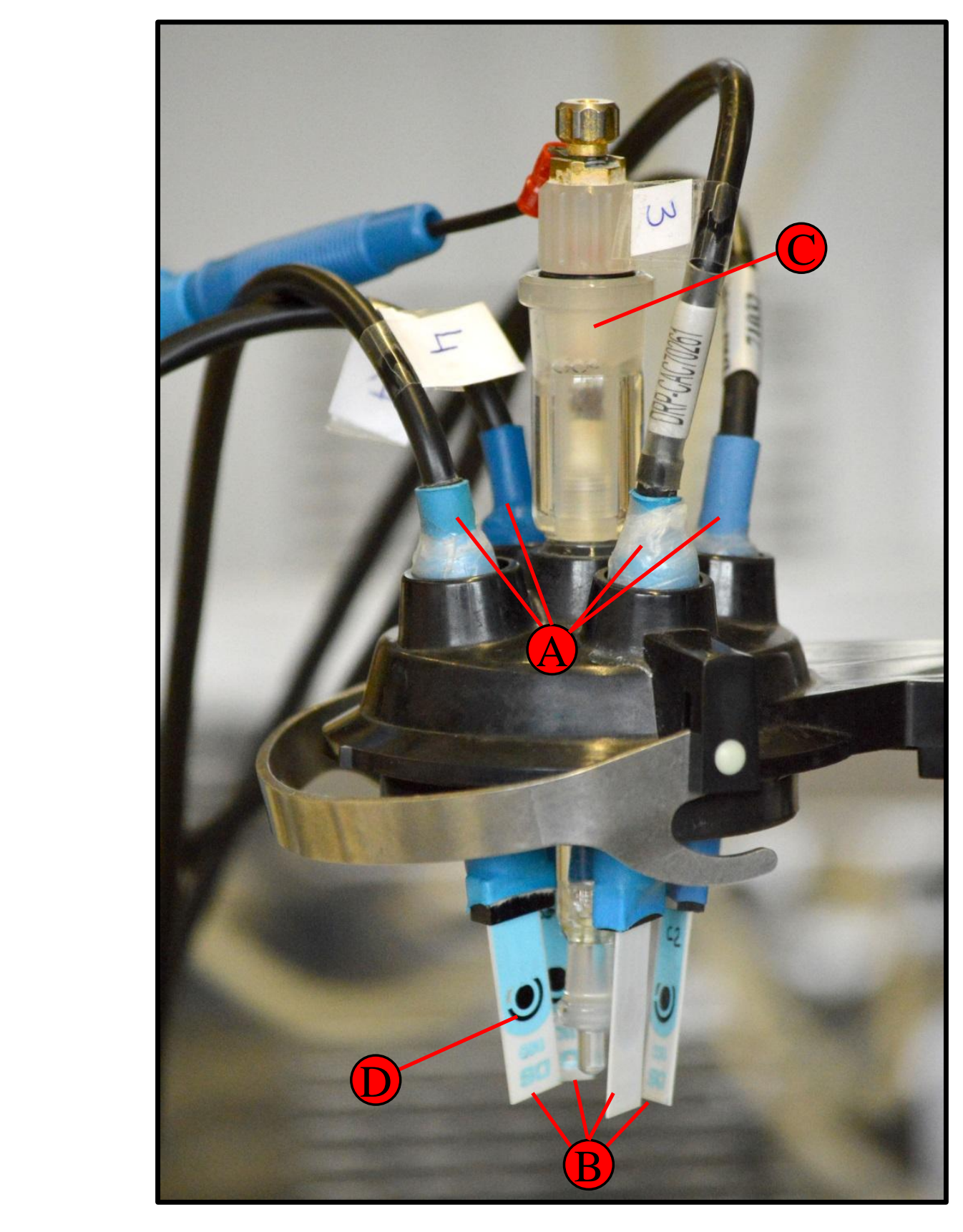

Figure 1

\section{Figure 1}

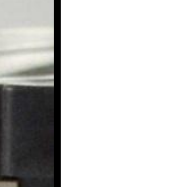


Figure 2

a)

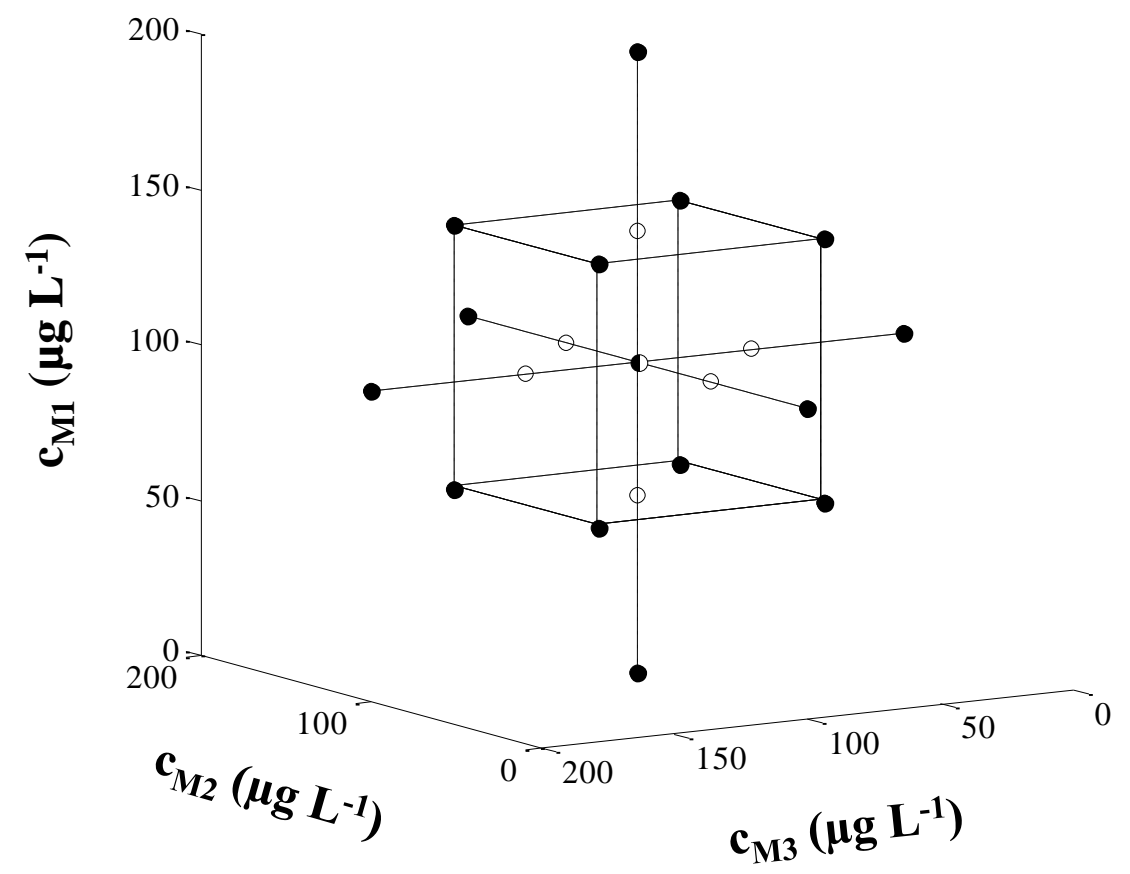

b)

)

SPCE-CNF
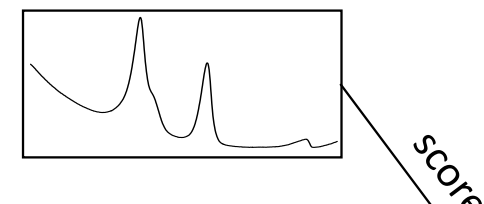

Cys-SPCE-CNF
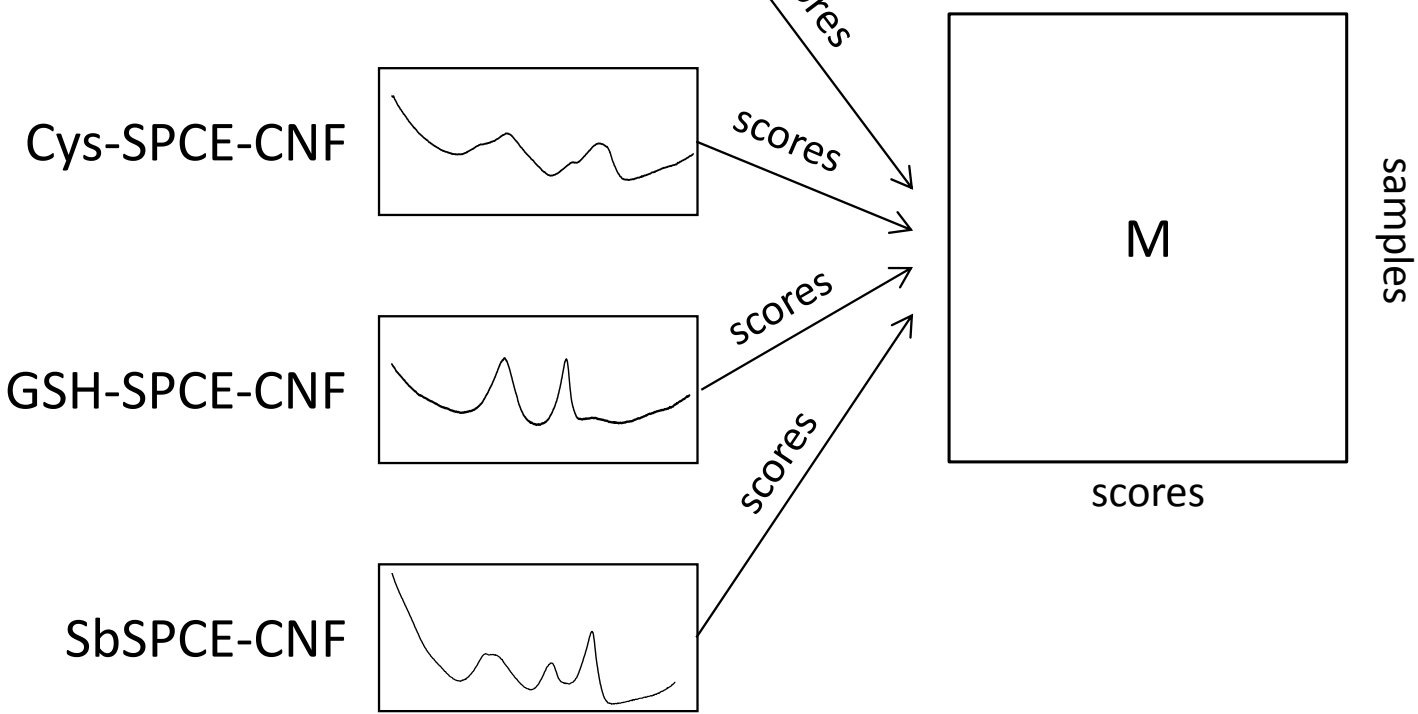

scores

$\frac{n}{3}$ 


\section{Figure 3}

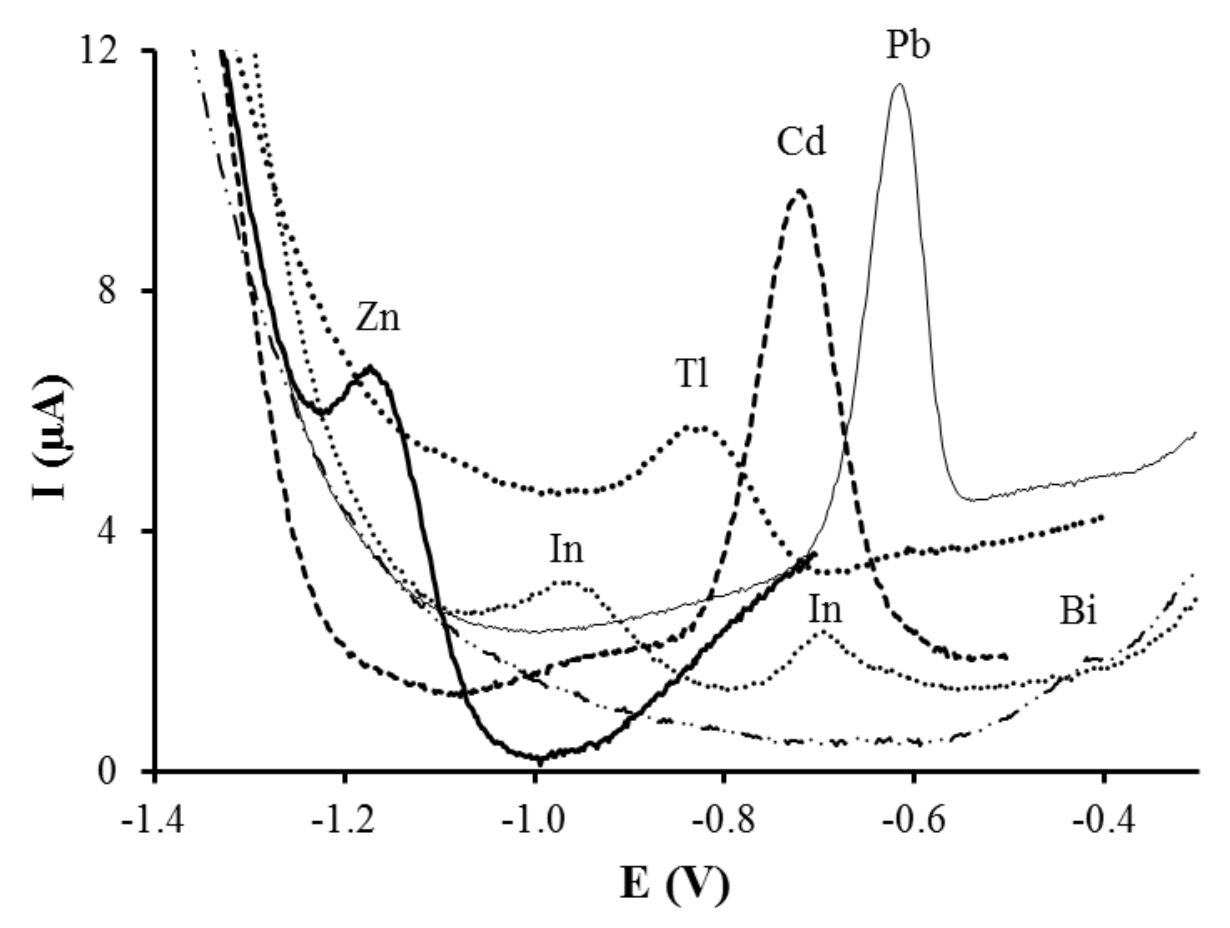

Figure 3 


\section{Figure 4}

a)

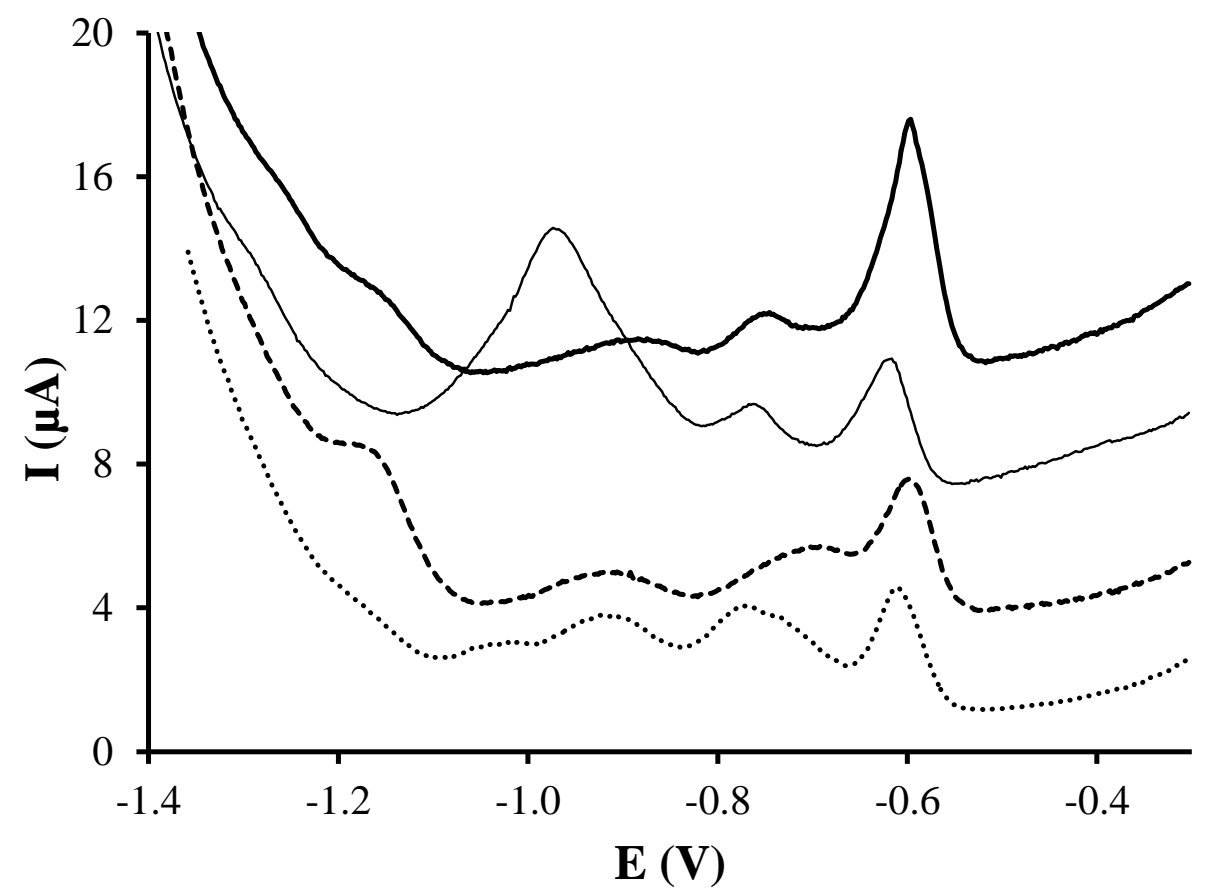

b)

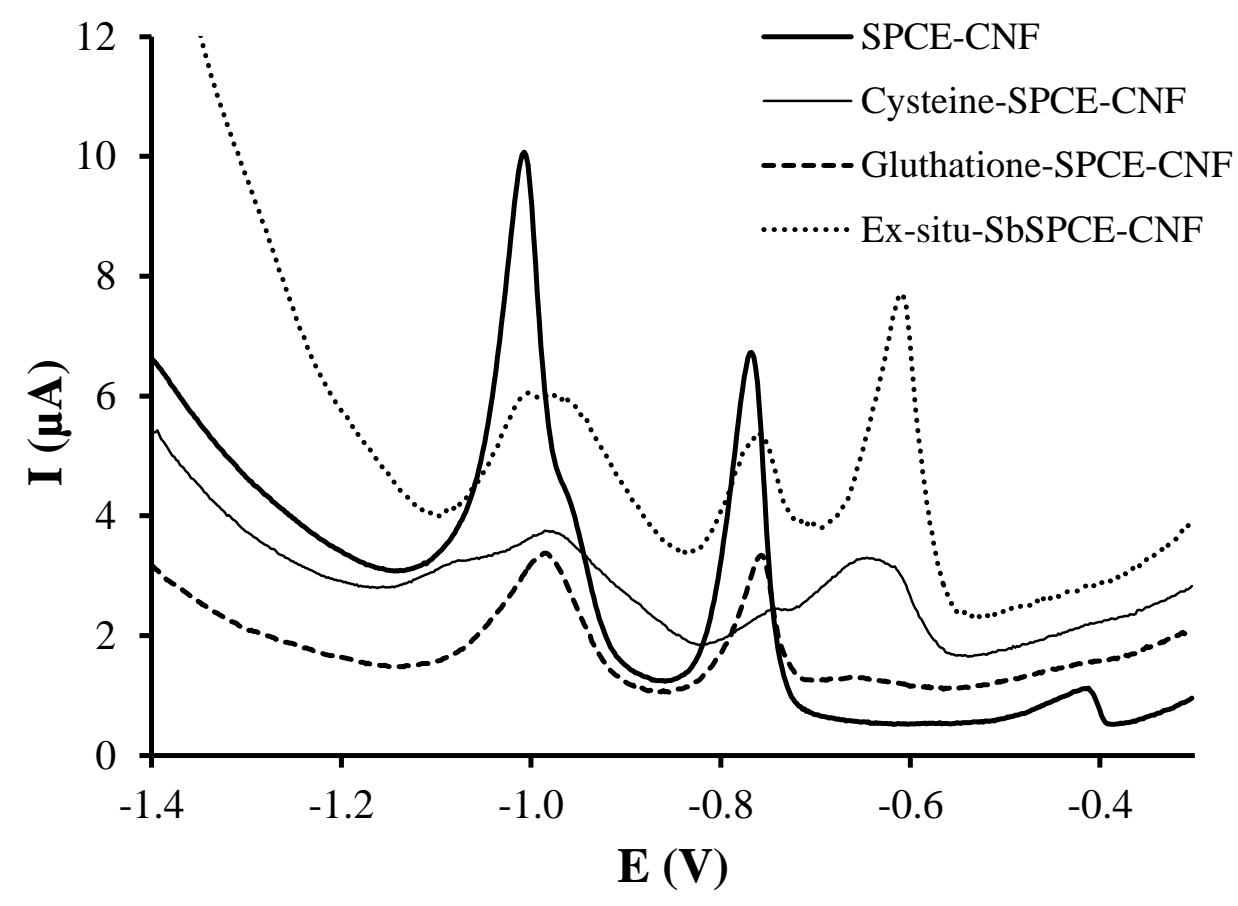



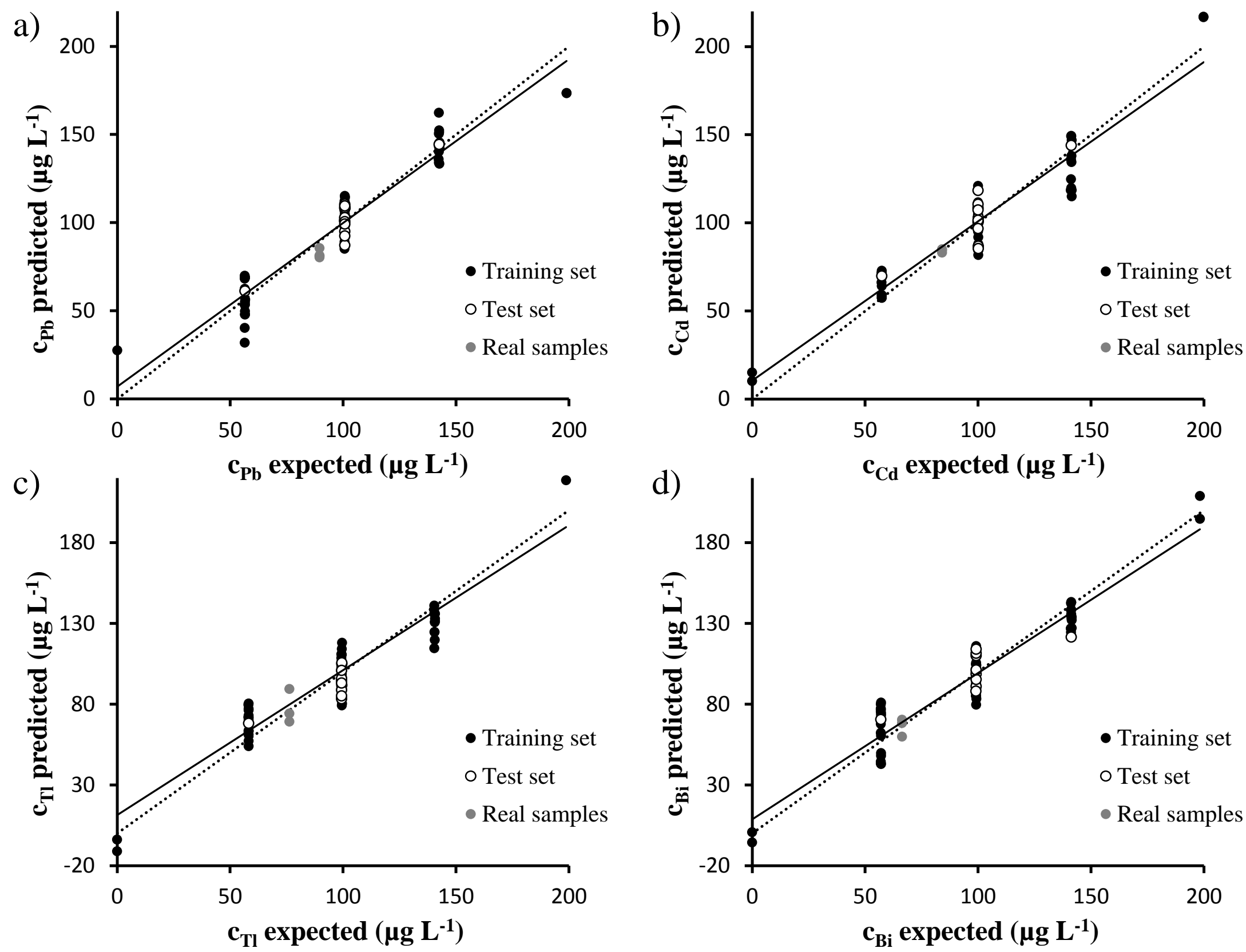